\title{
Relative importance of transport and alkylation for pancreatic beta-cell toxicity of streptozotocin
}

\author{
M. Elsner ${ }^{1}$, B. Guldbakke ${ }^{1}$, M. Tiedge ${ }^{1}$, R. Munday ${ }^{2}$, S. Lenzen ${ }^{1}$ \\ ${ }^{1}$ Institute of Clinical Biochemistry, Hannover Medical School, Hannover, Germany \\ ${ }^{2}$ AgResearch, Ruakura Agricultural Research Centre, Hamilton, New Zealand
}

\section{Abstract}

Aims/hypothesis. The role of selective uptake and alkylation in the diabetogenic action of streptozotocin was investigated in bioengineered RINm5F insulin-producing cells, with different expression levels of the glucose transporter GLUT2, by comparing the toxicity of streptozotocin with that of four chemically related alkylating compounds, $N$-methyl- $N$-nitrosourea (MNU), $N$-ethyl- $N$ nitrosourea (ENU), methyl methanesulphonate (MMS) and ethyl methanesulphonate (EMS).

Methods. GLUT2 expressing RINm5F cells were generated through stable transfection of the rat glucose transporter GLUT2 cDNA under the control of the cytomegalovirus promoter in the pcDNA3 vector. Viability of the cells was determined using a microtitre plate-based 3-[4,5-dimethylthiazol-2-yl]-2,5diphenyl tetrazolium bromide (MTT) assay.

Results. Cells expressing the glucose transporter GLUT2 were much more susceptible to streptozoto- cin toxicity than control cells due to the uptake of streptozotocin by this specific glucose transporter. In contrast, the GLUT2 expression had no effect upon the toxicity of MNU, ENU, MMS or EMS. Although the latter substances are, like streptozotocin, cytotoxic through their ability to cause DNA alkylation, they are not diabetogenic because they are not taken up through the glucose transporter GLUT2.

Conclusion/interpretation. Our results are consistent with the central importance of selective uptake and alkylating activity in the mechanism of streptozotocin diabetogenicity. Alkylation of DNA leads to necrosis of pancreatic beta cells and thus to a state of insulindependent diabetes mellitus, well-known as streptozotocin diabetes in experimental diabetes research. [Diabetologia (2000) 43: 1528-1533]

Keywords Streptozotocin, diabetes, RINm5F cells, streptozotocin derivatives, glucose transporter GLUT2.
The diabetogenic agent streptozotocin (STZ) [1-5] is a D-glucopyranose derivative of $N$-methyl- $N$-nitrosourea (MNU). Both STZ and MNU are potent alkylating agents [6], highly toxic and carcinogenic $[3,7]$ but only STZ is diabetogenic because of the se-

Received: 13 June 2000 and in revised form: 16 August 2000

Corresponding author: Prof. S. Lenzen, Institute of Clinical Biochemistry, Hannover Medical School, D-30623 Hannover, Germany

Abbreviations: STZ, streptozotocin; MNU, $N$-methyl- $N$-nitrosourea; MMS, methyl methanesulphonate; EMS, ethyl methanesulphonate; ENU, $N$-ethyl- $N$-nitrosourea; PARP, poly(ADP-ribose)polymerase. lective destruction of the insulin-producing beta cells resulting from necrosis $[8,9]$. It has been suggested that the selective beta-cell toxicity of STZ is related to the glucose moiety in its chemical structure which enables STZ to enter the beta cell via the low affinity glucose transporter GLUT2 in the plasma membrane [4]. This hypothesis is supported by the observation that the RINm5F rat insulinoma cell line, which does not express this glucose transporter, resists STZ toxicity $[10,11]$ and becomes sensitive to the toxic action of this compound only after expression of the GLUT2 glucose transporter in this cell line [12]. This observation could explain the greater toxicity of STZ when compared with MNU in GLUT2-express- 
<smiles>[Z]O[C@@H]1[C@H](NC(=O)N(C)[N+](=O)[O-])[C@@H](O)O[C@@H](CO[CH])[C@@H]1O</smiles>

B<smiles>CN(C(N)=O)[N+](=O)[O-]</smiles>
MNU<smiles>COS(C)(=O)=O</smiles>

MMS<smiles>CCN(CC)C(N)=O</smiles>
ENU

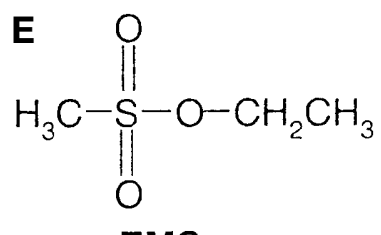

Fig. 1. Chemical structures of the alkylating agents streptozotocin (STZ) A, the methyl and ethyl nitrosoureas $N$-methyl- $N$-nitrosourea (MNU) B and $N$-ethyl- $N$-nitrosourea (ENU) $\mathbf{C}$ and the methanesulphonates methyl methanesulphonate (MMS) D and ethyl methanesulphonate (EMS) E

ing beta cells even though both substances alkylate DNA to a similar extent $[13,14]$.

Although the exact mechanism of the diabetogenic action of STZ has not been elucidated, it has generally been assumed that its toxic action relates to the DNA alkylating activity of its MNU moiety [6, 14-16], especially at the $\mathrm{O}^{6}$ position of guanine [17-19]. Damage to DNA by STZ apparently depletes $\mathrm{NAD}^{+}$, which in turn inhibits insulin biosynthesis and secretion and leads finally to beta-cell death through ATP depletion [15, 20, 21].

This concept has been convincingly confirmed recently by the observation that mice deficient in poly (ADP-ribose) polymerase (PARP) are resistant to beta-cell death mediated by STZ in spite of DNA fragmentation. The absence of PARP, which is activated by DNA damage, prevents the depletion of its cofactor NAD ${ }^{+}$and subsequent loss of ATP [22-25].

An alternative hypothesis proposes that some of the diabetogenic properties of STZ could relate not to its alkylating ability but to its potential to act as a nitric oxide donor [26]. Both STZ and MNU contain a nitroso group and could liberate nitric oxide [16, 27-31] in a manner similar to that of other nitric oxide donors such as sodium nitroprusside or 3-mor- pholinosydnonimine (SIN-1) [32]. To investigate the potential role of nitric oxide in the action of STZ and other nitrosoureas, we included the alkylating agent methyl methanesulphonate (MMS) which is not a nitric oxide donor [33].

The role of alkylation in beta-cell death could be further examined by the use of the ethylating agents $N$-ethyl- $N$-nitrosourea (ENU) and ethyl methanesulphonate (EMS). These ethylating agents are less toxic than their methylating counterparts [19, 33]. This has been attributed to $\mathrm{O}^{6}$-ethylguanine being 10 to 100 times less toxic than $\mathrm{O}^{6}$-methylguanine [19]. A lower toxicity of the ethylating agents could be evidence of a role for $\mathrm{O}^{6}$-alkylguanine in the mechanism of the toxic action of this group of alkylating compounds.

Thus STZ and the four other chemically related alkylating compounds, which, unlike STZ are not diabetogenic, are test agents with different chemical properties [33], which could help explain the mechanism responsible for the selective beta-cytotoxic action and subsequent diabetogenicity of STZ.

We therefore compared the toxicity of these five test compounds (Fig.1) using the MTT cytotoxicity assay, in control RINm5F insulin-producing tissue culture cells and in RINm5F cell clones overexpressing glucokinase or GLUT2. Both structures serve as main low-affinity-signal recognition entities for glucose-induced insulin secretion in beta cells and as such could be involved in mediating the toxicity of STZ.

\section{Materials and methods}

Materials. Streptozotocin was obtained from Alexis (San Diego, Calif., USA), MNU, MMS and EMS from Sigma (St. Louis, Mo., USA) and ENU from Serva (Heidelberg, Germany).

The cDNA coding for rat human beta-cell glucokinase was kindly provided by A. Permutt (St. Louis, Mo., USA), the cDNA of the rat GLUT2 and the anti-GLUT2 antibody by B. Thorens (Lausanne, Switzerland). The glucokinase antibody was generated in rabbits against rat recombinant liver glucokinase [34].

Restriction enzymes, the SP6/T7 transcription kit and the DIG nucleic acid detection kit were obtained from Boehringer (Mannheim, Germany). Immobilon-P polyvinylidene difluoride (PVDF) membranes were from Millipore (Bedford, Mass., USA). Peroxidase-labelled anti-rabbit-IgG antibody and BCA assay reagent were from Sigma (St. Louis, Mo., USA). Hybond $\mathrm{N}$ nylon membranes, the electrogenerated chemiluminescence (ECL) detection system, autoradiography films and 3-O-methyl $\left[1-{ }^{3} \mathrm{H}\right]$ glucose were from Amersham (Braunschweig, Germany).

Geneticin (G 418), lipofectamine and all other tissue culture equipment were from Gibco BRL (Gaithersburg, Md., USA). Guanidine thiocyanate was from Fluka (Neu-Ulm, Germany). All other reagents of analytical grade were from Merck (Darmstadt, Germany). 
mRNA

Protein

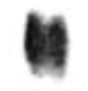

" "
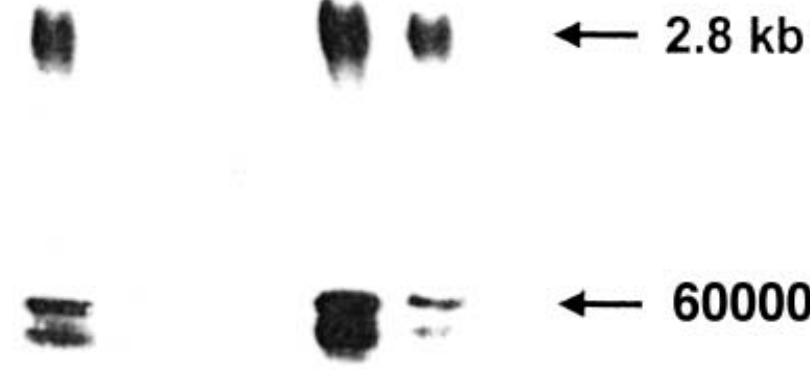

1

Fig. 2. Stable expression of GLUT2 in two clones (GLUT2-A and GLUT2-B) in insulin-producing RINm5F cells: (1) liver, (2) non-transfected control cells, (3) glucokinase-transfected cells and (4-5) clones A and B of GLUT2-transfected cells. RINm5F cells were transfected with human beta cell glucokinase cDNA or rat GLUT2 cDNA. Clones expressing GLUT2 were characterised by Western and Northern blot analyses for protein and mRNA expression, respectively. RNA $(10 \mu \mathrm{g})$ was hybridised with an antisense cRNA probe coding for rat GLUT2, protein $(30 \mu \mathrm{g})$ was analysed using an antibody against rat GLUT2. Representative blots are from 4 separate experiments. Control and glucokinase overexpressing RINm5F cells did not express the GLUT2. When compared with rat liver $(100 \%)$ the GLUT2 mRNA expression was $140 \pm 25 \%$ in clone $\mathrm{A}$ and $81 \pm 8 \%$ in clone $\mathrm{B}$; the GLUT2 protein expression was $183 \pm 23 \%$ in clone $A$ and $61 \pm 17 \%$ in clone $\mathrm{B}$.

Tissue culture and viability tests. The RINm5F insulin-producing tissue culture cells (passage 55-70) were cultured in RPMI 1640 medium, supplemented with $10 \mathrm{mmol} / \mathrm{l}$ glucose, $10 \%$ (v/ v) foetal calf serum, penicillin and streptomycin in a humidified atmosphere at $37^{\circ} \mathrm{C}$ and $5 \% \mathrm{CO}_{2}$ [35]. Control and transfected RINm5F cells were seeded at a concentration of $2 \cdot 10^{4}$ cells/well in $100 \mu \mathrm{l}$ culture medium in 96-well microplates, and incubated at $37^{\circ} \mathrm{C}$ with the test compounds. All test compounds were dissolved in $10 \mathrm{mmol} / 1 \mathrm{HCl}$ immediately before the experiment and added to HEPES (20 mmol/l) supplemented KRB medium without glucose for $1 \mathrm{~h}$. The buffer was then removed and the cells were incubated for another $18 \mathrm{~h}$ in RPMI 1640 medium. After the incubation period, the viability of the cells was determined using a microtitre-plate-based MTT assay [36] and expressed as a percentage of the untreated samples. Unless otherwise indicated experiments were done in HEPES (20 mmol/l) buffered Krebs-Ringer bicarbonate medium (pH 7.4) [37]. Glucokinase enzyme activities of RINm5FGK cells were measured according to a previous study [34]. The glucose transport of RINm5F cells was quantified as described previously [38]. The DNA content of RINm5F cells was measured according to a previous study [39].

Stable overexpression in RINm5F cells. The GLUT2-expressing RINm5F cells were generated through stable transfection of the rat GLUT2 cDNA [40] under the control of cytomegalovirus promoter in the pcDNA3 vector using lipofectamine [35]. Overexpression of glucokinase in RINm5F cells was done in an analogous manner resulting in a tenfold higher enzyme activity [34]. Transfected clones were selected through resistance against $\mathrm{G} 418$.
Northern blot analyses. The RINm5F cells were homogenised in buffered $4 \mathrm{~mol} / \mathrm{l}$ guanidine thiocyanate solution. Total RNA was isolated according to methods described previously [41]. $10 \mu \mathrm{g}$ of RNA per lane were separated through electrophoresis on denaturing formamide/formaldehyde $1 \%$ agarose gels and transferred to nylon membranes. We hybridised RNA using digoxigenin(DIG)-labelled antisense cRNA probes coding for rat GLUT2 [40]. The DIG-labelled hybrids were detected by an enzyme-linked immunoassay followed by chemiluminescence. The intensity of the bands was quantified through densitometry with the National Institutes of Health (NIH) Image 1.58 program (Bethesda, Md., USA).

Western blot analyses. The RINm5F cells were homogenised in Krebs-Ringer buffer by sonication on ice $(60 \mathrm{~W}, 3$ bursts of 10 s). Microsomal protein was prepared according to a previous study [42]. Protein was quantified by a bicinchoninic acid (BCA) assay with bovine albumin as standard. A total of $30 \mu \mathrm{g}$ RINm5F cell protein or microsomal protein were fractionated by reducing $10 \%$ sodium dodecyl sulphate (SDS) polyacrylamide gel electrophoresis and electroblotted to PVDF membranes. The membranes were stained by Ponceau to verify the transfer of comparable amounts of cellular protein. Non-specific binding sites of the membranes were blocked overnight by non-fat dry milk at $4{ }^{\circ} \mathrm{C}$. Thereafter the blots were incubated with specific primary antibody against rat GLUT2, at a dilution of $1: 10000$ overnight at $4{ }^{\circ} \mathrm{C}$, followed by a 2 -hour incubation with peroxidase-labelled secondary antibody at a dilution of 1:15000 at room temperature. The protein bands were visualised by electrogenerated chemiluminescence (ECL).

Statistical analyses. Data are expressed as means \pm SEM. Statistical analyses were done using one-way ANOVA followed by Dunnett's test for multiple comparisons. The $\mathrm{EC}_{50}$ was calculated from non-linear regression analysis using least square algorithms of the Prism analysis program (Graphpad, San Diego, Calif., USA).

\section{Results}

The RINm5F insulin-producing tissue culture cells which do not express the low affinity GLUT2 (Fig. 2) were extraordinarily resistant to the toxic effect of STZ (Fig. 3). The half maximally effective concentration $\left(\mathrm{EC}_{50}\right)$ of STZ, at which $50 \%$ of the cells had lost their viability in the MTT cytotoxicity assay, was $25 \mathrm{mmol} / \mathrm{l}$ (Table 1 ).

After transfection of the RINm5F cells with the GLUT2 (Fig.2), both clones (A and B) expressing 


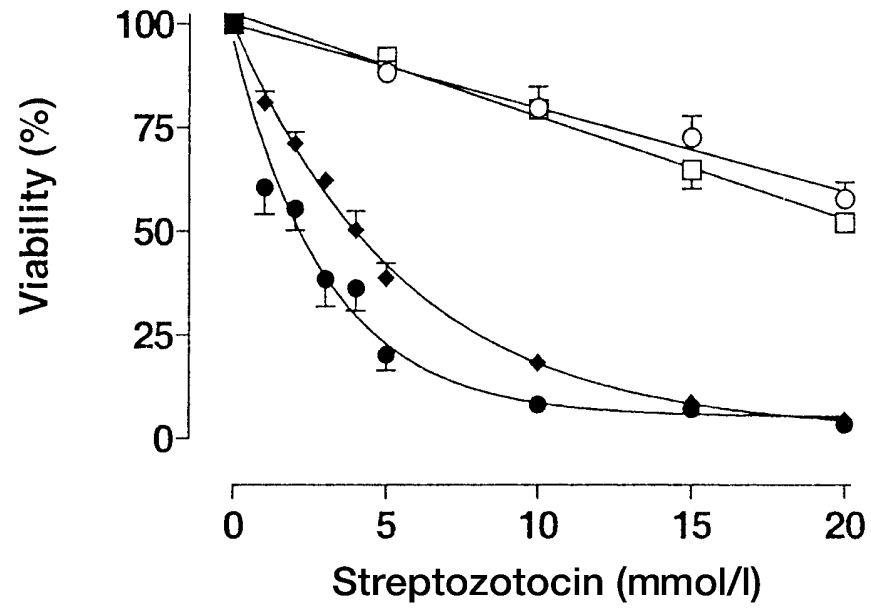

Fig.3. Effects of GLUT2 expression in insulin-producing RINm5F cells on the toxicity of STZ in the clones GLUT2-A ( ) and GLUT2-B ( ) compared with the glucokinase overexpressing clone $(\square)$ and with non-transfected RINm5F control cells $(\bigcirc)$. Viability was measured by the MTT assay depending on the STZ concentration and expressed as per cent of the untreated cells. Data are given as means \pm SEM from 5 experiments

this glucose transporter were sensitive to the toxic action of STZ as shown by the concentration-dependent loss of cell viability in the MTT assay (Fig. 3).

In both clones, the expression of the GLUT2 was in the range of that in the liver (Fig.3). Clone A, which had a higher mRNA and protein expression, was more susceptible to STZ toxicity than clone B (Fig. 3), as confirmed by the difference in the half maximally effective concentration $\left(\mathrm{EC}_{50}\right)$ of STZ in the MTT assay (2.1 vs $3.9 \mathrm{mmol} / \mathrm{l}$ ) (Fig. 3, Table 1 ).

At variance from the situation in the clones expressing the GLUT2, no increase in susceptibility to STZ was observed in the clone overexpressing glucokinase (Fig. 3) and the $\mathrm{EC}_{50}$ of STZ was not significantly different from that of the control cells (Table 1). This was confirmed in a control experiment in which glucokinase was overexpressed in a RINm5F cell clone with constitutive GLUT2 expres-

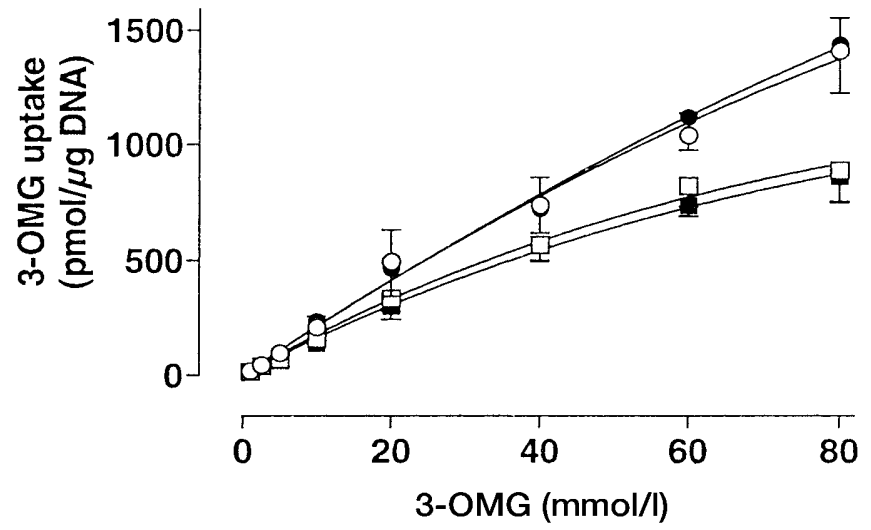

Fig. 4. Lack of effect of STZ $(5 \mathrm{mmol} / \mathrm{l})$ on $3-O$-methyl $\left[1-{ }^{3} \mathrm{H}\right]-$ glucose (3-OMG) uptake by the GLUT2 expressing GLUT2A clone ( and $\bigcirc$ ) compared with non-transfected control cells not expressing the GLUT2 ( $\square$ and $\square$ ) in presence ( and $\square$ ) and absence ( $\bigcirc$ and $\square$ ) of STZ ( $5 \mathrm{mmol} / \mathrm{l})$. The function of the GLUT2 protein in the transfected RINm5F cells ( $\mathrm{and} \bigcirc$ ) was confirmed by an up to 1.7 -fold higher 3-OMG uptake at $80 \mathrm{mmol} / \mathrm{l} 3-\mathrm{OMG}$ compared with non-transfected control cells ( $\square$ and $\square$ ). Incubations were done in the presence of $1-80 \mathrm{mmol} / \mathrm{l} 3-O$-methyl $\left[1-{ }^{3} \mathrm{H}\right]$ glucose $(6 \mu \mathrm{Ci} / \mathrm{ml})$ for $15 \mathrm{~s}$. Data are shown as means \pm SEM from 4 experiments

sion [43] where the susceptibility towards STZ toxicity in the MTT assay was also unchanged (unpublished data).

The aglycone of STZ, MNU, was as toxic to control RINm5F cells as to those expressing the GLUT2 or glucokinase. The $\mathrm{EC}_{50}$ was in the range of the values obtained for STZ in the GLUT2 expressing cell clones (Table 1). There was, however, no significant difference in the $\mathrm{EC}_{50}$ values for control and transfected cells (Table 1), proving that it is the glucose moiety that allows the selectivity in the toxic action of STZ. Although STZ uses the low affinity GLUT2 to enter the cell, it does not disturb its function, as is shown by the lack of effect on $3-O$-methyl $\left[1-{ }^{3} \mathrm{H}\right]$ glucose uptake into GLUT2 expressing RINm5F cells (A-clone, Fig. 4; B-clone, data not shown).

The MMS was also toxic to RINm5F cells, again without showing any selectivity in its toxicity. In par-
Table 1. Half maximal concentrations $\left(\mathrm{EC}_{50}\right)$ for toxicity in the MTT assay of the alkylating agents streptozotocin (STZ), the methyl and ethyl nitrosoureas $N$-methyl- $N$-nitrosourea
(MNU) and $N$-ethyl- $N$-nitrosourea (ENU) and the methanesulphonates methyl methanesulphonate (MMS) and ethyl methanesulphonate (EMS)

\begin{tabular}{lrrrr}
\hline $\begin{array}{l}\text { Test compound } \\
\text { EC }_{50}\end{array}$ & $\begin{array}{l}\text { RINm5F } \\
(\mathrm{mmol} / \mathrm{l})\end{array}$ & \multicolumn{1}{l}{$\begin{array}{l}\text { RINm5F-GK } \\
(\mathrm{mmol} / \mathrm{l})\end{array}$} & \multicolumn{1}{l}{$\begin{array}{l}\text { RINm5F-GLUT2-A } \\
(\mathrm{mmol} / \mathrm{l})\end{array}$} & $\begin{array}{l}\text { RINm5F-GLUT2-B } \\
(\mathrm{mmol} / \mathrm{l})\end{array}$ \\
\hline STZ & $25.1 \pm 0.4(5)$ & $20.5 \pm 0.3(5)$ & $2.1 \pm 0.2(5)^{*}$ & $3.9 \pm 0.3(5)^{*}$ \\
MNU & $2.7 \pm 0.2(7)$ & $2.5 \pm 0.1(6)$ & $2.8 \pm 0.2(5)$ & $2.5 \pm 0.1(4)$ \\
ENU & $4.7 \pm 0.4(4)$ & $5.4 \pm 0.3(4)$ & $4.8 \pm 0.4(4)$ & $4.4 \pm 0.3(4)$ \\
MMS & $0.8 \pm 0.1(4)$ & $1.0 \pm 0.1(4)$ & $1.1 \pm 0.1(4)$ & $0.9 \pm 0.1(4)$ \\
EMS & $27.2 \pm 0.6(4)$ & $30.4 \pm 1.0(4)$ & $34.6 \pm 0.9(4)$ & $32.3 \pm 1.0(4)$ \\
\hline
\end{tabular}

Data are means \pm SEM. Numbers of experiments given in parentheses. Cells were exposed to serial concentrations of the test compounds as used in the concentration dependencies shown in Fig. 1. Viability of the cells was determined by the
MTT assay. The $\mathrm{EC}_{50}$ values were calculated by non-linear regression analyses. ${ }^{*} p<0.01$ compared with non-transfected control RINm5F cells 
ticular this applied to the GLUT2-expressing RINm5F-cell clones which were no more sensitive to the toxic action of MMS than the control cells or glucokinase overexpressing cells (Table 1). Since MMS, unlike MNU, does not generate nitric oxide during decomposition (Fig. 1) this indicates that nitric oxide is not required for the toxic action of this group of alkylating agents including the diabetogenic compound STZ.

Both ENU and EMS were significantly less toxic to RINm5F cells than MNU and MMS, as shown by the significantly higher $\mathrm{EC}_{50}$ values in the MTT cytotoxicity assay (Table 1). This supports the contention that in these RINm5F insulin-producing cells, as in other cell types, the mechanism of toxic action is due to alkylation [6], with the methylation of DNA bases being more toxic than the ethylation [19]. Again, the ethyl derivatives were not selectively toxic (Table 1 ).

\section{Discussion}

Our results, together with previous observations mentioned above, explain the mechanism of the beta-cell toxic and diabetogenic action of STZ as follows:

1. The toxic action of STZ and chemically related alkylating compounds requires their uptake into the cells (Fig. 3).

2. STZ causes beta-cell death and is diabetogenic because it is taken up selectively by beta cells through the low affinity glucose transporter GLUT2 [12].

3 . The glucose moiety in the structure of the molecule (Fig.1) enables STZ to be transported into the beta cell through this specific glucose transporter.

4. In insulin-producing cells not expressing the GLUT2, the cellular uptake of STZ is very slow. Correspondingly low is the toxicity (Fig. 3).

5 . The importance of the GLUT2 is also confirmed by the observation of STZ damage to other cells expressing this transporter such as hepatocytes and renal tubular cells [40]. Thus any STZ treatment of animals leads not only to diabetes but also to liver and kidney damage [1].

6. Glucokinase, the low affinity glucose phosphorylating enzyme and glucose sensor of the beta cell, which, in concert with the GLUT2, is responsible for generating the metabolic signal for glucose-induced insulin secretion [43] is not actively involved in mediating the toxic action of STZ. The expression level of glucokinase is thus not important, at variance from the GLUT2. In particular there seems to be no critical interaction between these low affinity glucose recognition structures in mediating the beta-cell toxicity of STZ.

7. Toxicity of STZ and related agents resides in their ability to alkylate DNA [6]. Such DNA damage causes, along a defined chain of events [25], necrosis of beta cells [9]. The concomitant activation of poly (ADP-ribose) polymerase (PARP) depletes NAD ${ }^{+}$ and subsequently also ATP by overstimulation of the DNA repair mechanisms [25].

As STZ is the glycone of MNU, a member of the chemical group of the nitrosoureas which for decades have been used due to their DNA toxicity as anti-cancer drugs, it is not surprising that the cytotoxic activity of STZ originates from the nitrosomethylurea moiety in its chemical structure.

8. Nitric oxide generation is apparently not a prerequisite for the toxic action of all compounds of this group. This is supported by the observation that MMS which does not generate nitric oxide [33] is more toxic than the nitrosoureas MNU and ENU (Table 1).

In conclusion, it is possible to explain the mechanism underlying the necrotic beta-cell destruction in STZ diabetes, as a result of selective uptake of the compound through the low affinity GLUT2 into the beta cell and subsequent destruction through DNA damage. In chemical terms it is the glucose molecule in the structure which gives way to selective uptake of STZ into the beta cell, while the MNU nitrosourea moiety of STZ allows for its activity as an alkylating agent.

Acknowledgements. Some of the results were obtained from thesis work by B. Guldbakke. The authors are most grateful to Prof. I. C. Green and Prof. M. H. L. Green (Brighton) for advice.

\section{References}

1. Rerup CC (1970) Drugs producing diabetes through damage of the insulin secreting cells. Pharmacol Rev 22: 485-518

2. Anderson T, Schein PS, McMenamin MG, Cooney DA (1974) Streptozotocin diabetes. Correlation with extent of depression of pancreatic islet nicotinamide adenine dinucleotide. J Clin Invest 54: 672-677

3. Weiss RB (1982) Streptozocin: a review of its pharmacology, efficacy, and toxicity. Cancer Treat Rep 66: 427-438

4. Preston AM (1985) Modification of streptozotozin-induced diabetes by protective agents. Nutr Res 5: 435-446

5. Wang Z, Gleichmann H (1998) GLUT2 in pancreatic islets: crucial target molecule in diabetes induced with multiple low doses of streptozotocin in mice. Diabetes 47: 50-56

6. Bennett RA, Pegg AE (1981) Alkylation of DNA in rat tissues following administration of streptozotocin. Cancer Res 41: 2786-2790

7. Schein PS, O'Connell MJ, Blom J et al. (1974) Clinical antitumor activity and toxicity of streptozotocin (NSC-85998). Cancer 34: 993-1000

8. Gunnarsson R, Berne C, Hellerstrom C (1974) Cytotoxic effects of streptozotocin and N-nitrosomethylurea on the pancreatic B cells with special regard to the role of nicotinamide- adenine dinucleotide. Biochem J 140: 487-494

9. Lenzen S, Tiedge M, Jörns A, Munday R (1996) Alloxan derivatives as a tool for the elucidation of the mechanism of the diabetogenic action of alloxan. In: Shafrir E (ed) 
Lessons from Animal Diabetes, Birkhäuser, Boston, pp 113-122

10. Ledoux SP, Wilson GL (1984) Effects of streptozotocin on a clonal isolate of rat insulinoma cells. Biochim Biophys Acta 804: 387-392

11. Flatt PR, Swanston-Flatt SK, Tan KS, Marks V (1987) Effects of cytotoxic drugs and inhibitors of insulin secretion on a serially transplantable rat insulinoma and cultured rat insulinoma cells. Gen Pharmacol 18: 293-297

12. Schnedl WJ, Ferber S, Johnson JH, Newgard CB (1994) STZ transport and cytotoxicity. Specific enhancement in GLUT2- expressing cells. Diabetes 43: 1326-1333

13. LeDoux SP, Woodley SE, Patton NJ, Wilson GL (1986) Mechanisms of nitrosourea-induced beta-cell damage. Alterations in DNA. Diabetes 35: 866-872

14. Wilson GL, Hartig PC, Patton NJ, LeDoux SP (1988) Mechanisms of nitrosourea-induced beta-cell damage. Activation of poly (ADP-ribose) synthetase and cellular distribution. Diabetes 37: 213-216

15. Uchigata Y, Yamamoto $\mathrm{H}$, Kawamura A, Okamoto $\mathrm{H}$ (1982) Protection by superoxide dismutase, catalase, and poly(ADP-ribose) synthetase inhibitors against alloxanand streptozotocin-induced islet DNA strand breaks and against the inhibition of proinsulin synthesis. J Biol Chem 257: 6084-6088

16. Murata M, Takahashi A, Saito I, Kawanishi S (1999) Sitespecific DNA methylation and apoptosis: induction by diabetogenic streptozotocin. Biochem Pharmacol 57: 881-887

17. Goldmacher VS, Cuzick RA Jr, Thilly WG (1986) Isolation and partial characterization of human cell mutants differing in sensitivity to killing and mutation by methylnitrosourea and $\mathrm{N}$ - methyl-N'-nitro-N-nitrosoguanidine. J Biol Chem 261: 12462-12471

18. Green MH, Lowe JE, Petit-Frere C, Karran P, Hall J, Kataoka H (1989) Properties of $N$-methyl- $N$-nitrosourea-resistant, Mex- derivatives of an SV40-immortalized human fibroblast cell line. Carcinogenesis 10: 893-898

19. Karran P, Bignami M (1992) Self-destruction and tolerance in resistance of mammalian cells to alkylation damage. $\mathrm{Nu}$ cleic Acids Res 20: 2933-2940

20. Yamamoto H, Uchigata Y, Okamoto H (1981) Streptozotocin and alloxan induce DNA strand breaks and poly(ADPribose) synthetase in pancreatic islets. Nature 294: 284-286

21. Yamamoto H, Uchigata Y, Okamoto H (1981) DNA strand breaks in pancreatic islets by in vivo administration of alloxan or streptozotocin. Biochem Biophys Res Commun 103: $1014-1020$

22. Pieper AA, Brat DJ, Krug DK et al. (1999) Poly(ADP-ribose) polymerase-deficient mice are protected from streptozotocin-induced diabetes. Proc Natl Acad Sci U S A 96: 3059-3064

23. Burkart V, Wang ZQ, Radons J, Heller B, Herceg Z, Stingl L, Wagner EF, Kolb H (1999) Mice lacking the poly(ADPribose) polymerase gene are resistant to pancreatic betacell destruction and diabetes development induced by streptozocin. Nat Med 5: 314-319

24. Masutani M, Suzuki H, Kamada N et al. (1999) Poly(ADPribose) polymerase gene disruption conferred mice resistant to streptozotocin-induced diabetes. Proc Natl Acad Sci U S A 96: 2301-2304

25. Pieper AA, Verma A, Zhang J, Snyder SH (1999) Poly (ADP-ribose) polymerase, nitric oxide and cell death. Trends Pharmacol Sci 20: 171-181

26. Turk J, Corbett JA, Ramanadham S, Bohrer A, McDaniel ML (1993) Biochemical evidence for nitric oxide formation from streptozotocin in isolated pancreatic islets. Biochem Biophys Res Commun 197: 1458-1464
27. Kwon NS, Lee SH, Choi CS, Kho T, Lee HS (1994) Nitric oxide generation from streptozotocin. FASEB J 8: 529-533

28. Rogers NE, Ignarro LJ (1992) Constitutive nitric oxide synthase from cerebellum is reversibly inhibited by nitric oxide formed from L-arginine. Biochem Biophys Res Commun 189: 242-249

29. Bedoya FJ, Solano F, Lucas M (1996) N-monomethyl-arginine and nicotinamide prevent streptozotocin-induced double strand DNA break formation in pancreatic rat islets. Experientia 52: 344-347

30. Kaneto H, Fujii J, Seo HG et al. (1995) Apoptotic cell death triggered by nitric oxide in pancreatic beta-cells. Diabetes 44: 733-738

31. Kroncke KD, Fehsel K, Sommer A, Rodriguez ML, KolbBachofen V (1995) Nitric oxide generation during cellular metabolization of the diabetogenic $N$-methyl- $N$-nitrosourea streptozotozin contributes to islet cell DNA damage. Biol Chem Hoppe Seyler 376: 179-185

32. Tiedge M, Lortz S, Munday R, Lenzen S (1999) Protection against the co-operative toxicity of nitric oxide and oxygen free radicals by overexpression of antioxidant enzymes in bioengineered insulin-producing RINm5F cells. Diabetologia 42: 849-855

33. Delaney CA, Dunger A, Di Matteo M, Cunningham JM, Green MH, Green IC (1995) Comparison of inhibition of glucose-stimulated insulin secretion in rat islets of Langerhans by streptozotocin and methyl and ethyl nitrosoureas and methanesulphonates. Lack of correlation with nitric oxide-releasing or $\mathrm{O}^{6}$-alkylating ability. Biochem Pharmacol 50: 2015-2020

34. Tiedge M, Steffeck H, Elsner M, Lenzen S (1999) Metabolic regulation, activity state, and intracellular binding of glucokinase in insulin-secreting cells. Diabetes 48: 514-523

35. Tiedge M, Lortz S, Drinkgern J, Lenzen S (1997) Relation between antioxidant enzyme gene expression and antioxidative defense status of insulin-producing cells. Diabetes 46: 1733-1742

36. Korting HC, Schindler S, Hartinger A, Kerscher M, Angerpointner T, Maibach HI (1994) MTT-assay and neutral red release (NRR)-assay: relative role in the prediction of the irritancy potential of surfactants. Life Sci 55: 533-540

37. Lenzen S (1979) Insulin secretion by isolated perfused rat and mouse pancreas. Am J Physiol 236: E391-E400

38. Tiedge M, Hohne M, Lenzen S (1993) Insulin secretion, insulin content and glucose phosphorylation in RINm5F insulinoma cells after transfection with human GLUT2 glucose- transporter cDNA. Biochem J 296: 113-118

39. Rago R, Mitchen J, Wilding G (1990) DNA fluorometric assay in 96-well tissue culture plates using Hoechst 33258 after cell lysis by freezing in destilled water. Anal Biochem 191: 31-34

40. Thorens B, Sarkar HK, Kaback HR, Lodish HF (1988) Cloning and functional expression in bacteria of a novel glucose transporter present in liver, intestine, kidney, and beta-pancreatic islet cells. Cell 55: 281-290

41. Chomczynski P, Sacchi N (1987) Single-step method of RNA isolation by acid guanidinium thiocyanate-phenolchloroform extraction. Anal Biochem 162: 156-159

42. Weiser MM (1973) Intestinal epithelial cell surface membrane glycoprotein synthesis. II. Glycosyltransferases and endogenous acceptors of the undifferentiated cell surface membrane. J Biol Chem 248: 2542-2548

43. Tiedge M, Elsner M, McClenaghan NH et al. (2000) Engineering of a glucose-responsive surrogate cell for insulin replacement therapy of experimental insulin-dependent diabetes. Hum Gene Ther 11: 403-414 